\title{
ISLAND HISTORY, NOT THE STORY OF ISLANDS: THE CASE OF ST HELENA
}

[Received November 11th 2018; accepted January 7th 2019 - DOI: 10.21463/shima.13.1.o6]

$$
\text { Stephen A. Royle }
$$

Queens University Belfast <s.royle@qub.ac.uk>

\begin{abstract}
This article makes distinctions between stories of islands and island history, between descriptions of individual islands and the subject matter of Island Studies. St Helena is used as the case study, not during its days on the global stage as the prison for Napoleon, but earlier, when it was a revictualing station for East India Company ships returning from the Orient. Events and stories on St Helena during this period are seen to be part of a much wider historical setting of global trade and nascent imperialism. International contestation played a role, too, with the island changing hands twice in 1673 when the Dutch conquerors were displaced by the English navy. Following recapture, the earlier attempts of the East India Company to establish a utopian society on their island were abandoned and a harsh regime imposed, which was met with sedition, mutiny and a slave rebellion. The article concludes with a discussion of the growing realisation of the significance of St Helena and other islands to the study of imperial history.
\end{abstract}

KEYWORDS: Islands, History, St Helena, East India Company, Slavery

\section{Introduction}

Every island has its story: what happened to it/on it from its foundation to the present. For example, Charles Maclean (2006) has written Island on the Edge of the World: The Story of St Kilda. An earlier account of St Kilda - A Voyage to St Kilda - formed a major element of Martin Martin's 1703 book, A Description of the Western Isles of Scotland; the same title Donald Monro used for his earlier work, written in 1549 although not published fully until 1805. "Story" and "description" are words used to indicate that the works to which they are appended are focused on just their island subjects. Now consider the instructions to potential authors for Island Studies Journal on its website, which state that:

In order to be accepted for publication, a paper needs to place island processes or "islandness" at the centre of its analysis; it is not enough for an article to simply concern a place that happens to be an island.

Thus a modern Martin Martin would have to do more than just describe St Kilda to achieve publication in that academic outlet, for Island Studies Journal is more than just a vehicle for the conveyance of stories and descriptions of islands. Modern scholarship - also the veneration and validation offered to certain past publications - requires consideration of those "island processes." It was not the description of the beaks of the finches on different islands of the Galapagos that was important in Darwin's theory of evolution, it was the conclusions drawn from the analysis of the different beak shapes and what this meant for evolution (and also for "islandness," although this word had not then been coined). A similar distinction can be seen within the study of island literature. At one level R.M. Ballantyne's Coral Island (1858) is an adventure yarn involving children "on a place that happens to be

Shima <www.shimajournal.org $>$ ISSN: 1834-6057 


\section{Royle: Island History/St Helena}

an island." An island setting for a work of fiction can have the advantages of limiting/making manageable the sizes of both stage and cast, and islands have been used for these purposes by authors as different in style as William Shakespeare and Agatha Christie. However, an alternative, deeper, reading of Coral Island, reinforced by William Golding's dystopian retelling in Lord of the Flies (1954), sees the novels as not just adventure yarns but as studies of leadership, of hierarchies and of imperialism. Coral Island is a 'Robinsonade' (a genre of island fiction that derives from Defoe's Robinson Crusoe [1719]) and Robinsonades are accepted and, indeed, theorised in serious literary studies (Kinane, 2016).

The same distinction between story and study might be made about the subject of history, which, in spite of the word's second syllable, is more than just a compendium of individual narratives. Thus "island history," as in the title of this article, cannot just deal with the story of islands. Take as a case the island of St Helena, situated in the South Atlantic between Angola and Brazil. The example of St Helena comes not from its time of renown when it was the place of incarceration of first Napoleon and then Boer prisoners from the South African War, but for an earlier period during its first couple of centuries of human habitation.

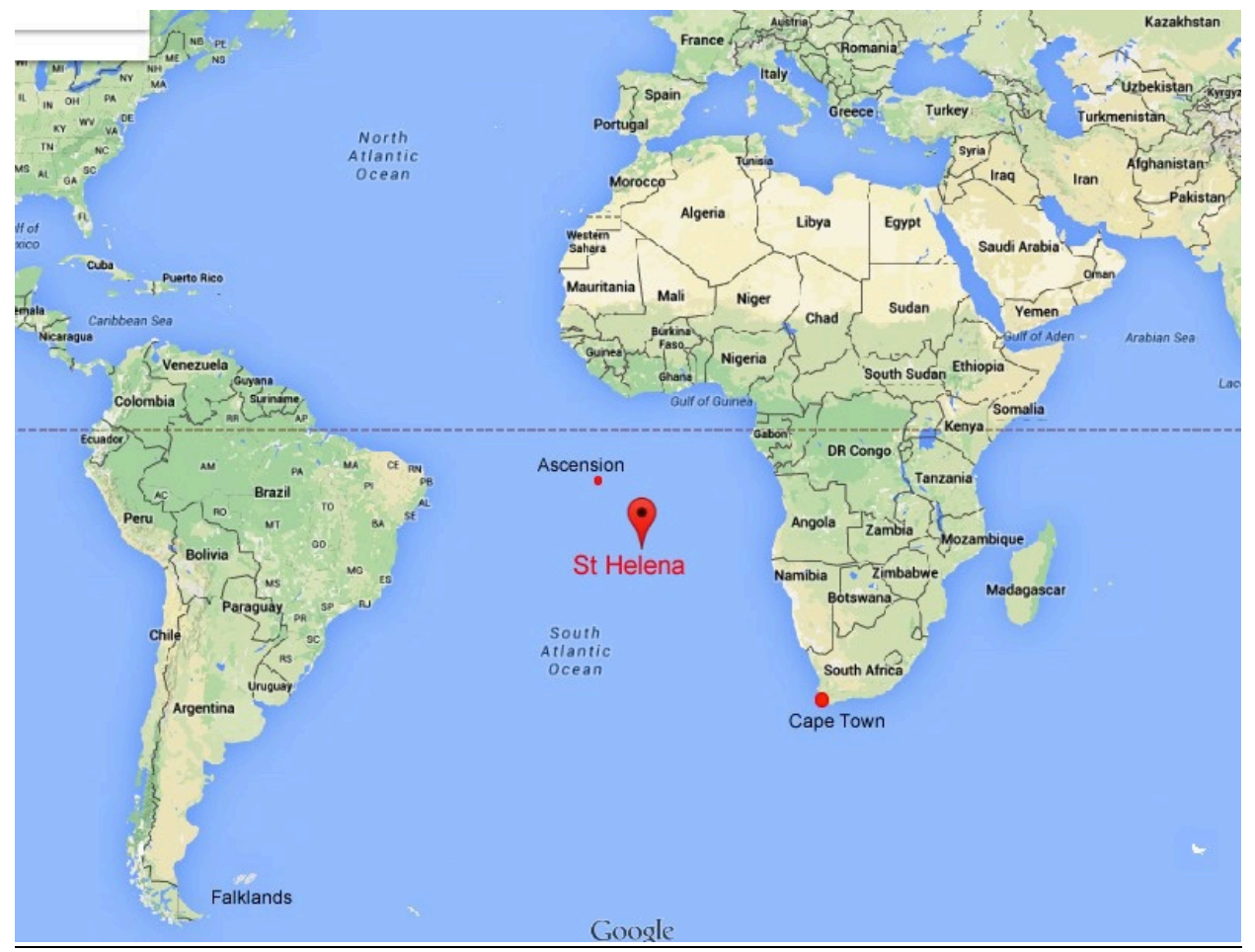

Figure 1 - The location of St Helena (Google Maps, 2018). 


\section{Royle: Island History/St Helena}

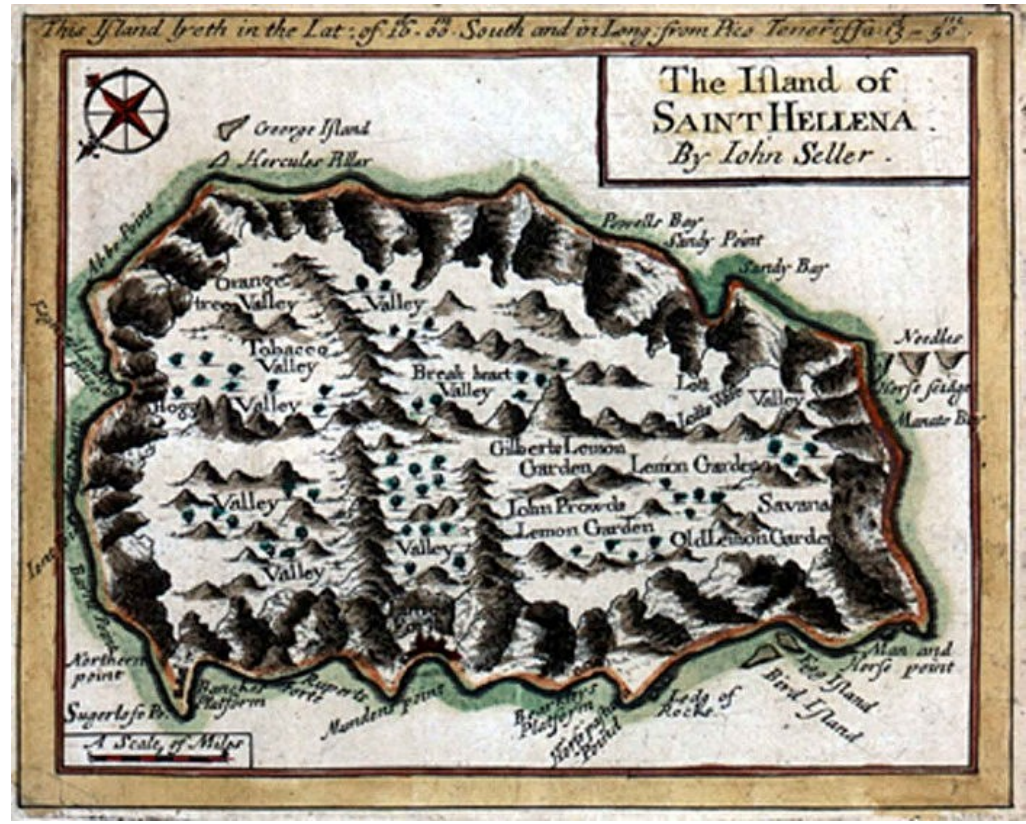

Figure 2 - A postcard of John Seller's 1675 map of St Helena

The story of early St Helena

St Helena was discovered by the Portuguese on St Helen's Day, 21st May, 1502. The Portuguese did not settle, but stocked the uninhabited island with livestock and planted fruit trees and herbs. Rival trading nations contested use of the island and there was a skirmish between the Portuguese and Dutch in 1613, which saw the Witte Leuw, a ship of the Vereenigde Oostindische Compagnie (VOC, the Dutch East India Company), sent to the bottom. The English East India Company (EIC) had begun to make regular visits to St Helena from 1603 and in 1659 the EIC annexed the island under a charter from Richard Cromwell, Oliver's son, who for a brief time succeeded his father as Lord Protector of England. The EIC had an expedition to hand because the company had organised ships to be sent to annex the island of Run in the Banda Islands (in the east of present-day Indonesia) but this venture had had to be postponed and the ships had not sailed. The commander, Richard Dutton, was instead sent to St Helena:

In the name of his Highnesse Richard, Lord Protector... and for the use of the Honourable English East India Company... take possession of the island and with Drum and Trumpett proclaim the same. ${ }^{1}$

Dutton arrived on 5th May 1659 and immediately built St Helena's first fort, Fort James. Dutton was sent on to Run in 166o, but his deputy remained on St Helena as "the said Island shall bee possessed and kept to". ${ }^{2}$ The EIC settled St Helena and migrants sent to "The

\footnotetext{
${ }^{1}$ British Library (BL), IOR E/3/85, f. 96-96v, 11th January 1659.

${ }^{2}$ BL, IOR E/3/85: 177-179, 19th December 1660.
} 


\section{Royle: Island History/St Helena}

Company's Island" (Royle, 2007) were instructed to "live together in love and amity", 3 if with "due obedience" to the governor and the observance of company orders under pain of "speedy removal".

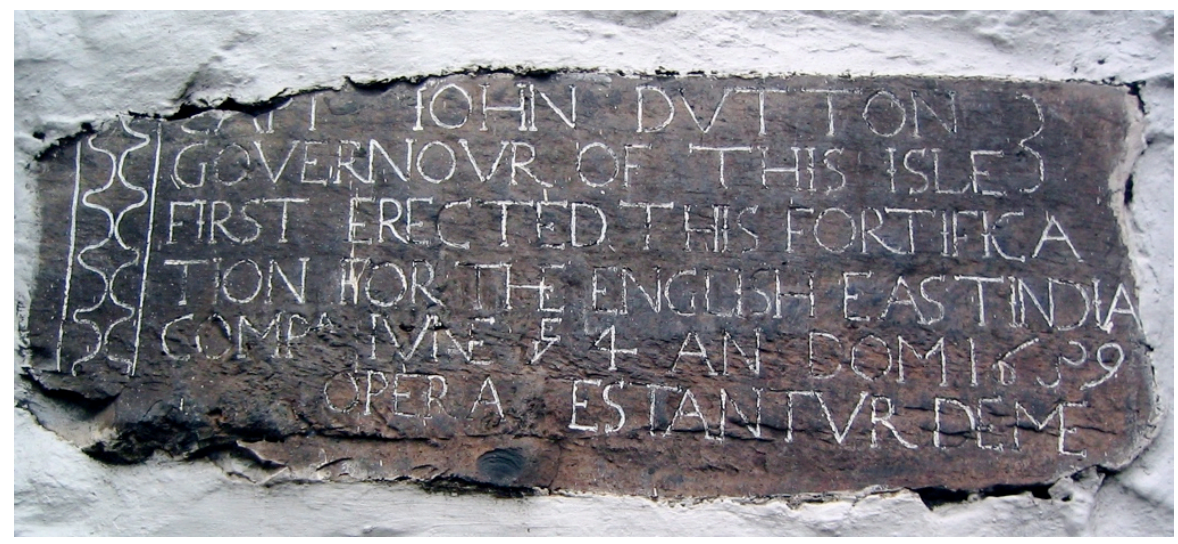

Figure 2 - Plaque affixed by John Dutton to the original Fort James, 1659. (Photo: Stephen Royle, 2004.)

The VOC had claimed St Helena in 1633 and contested possession with the EIC. St Helena changed hands in 1673 when a squadron of four Dutch ships captured the island and the inhabitants escaped (Boxer, 1930). The English navy ${ }^{5}$ recaptured the island later the same year and the EIC petitioned the king for return of St Helena to company possession. The company resettled the island, but under a harsher regime which saw sedition from the inhabitants in 1684, a mutiny in 1693 and a slave rebellion in 1695 .

\section{The history of early St Helena}

Such is St Helena's early story, a series of events. To turn the story into history, to turn the tale of the island into an Island Studies project, explanation and context for these events are required. Tiny St Helena was, even then, centuries before its Napoleonic heyday, participating globally and its history cannot be understood without reference to this much wider world. Discovery of St Helena from the deck or, presumably, masthead of a sailing ship was seemingly inevitable for as a 17th Century sailing master, observed, after rounding the Cape of Good Hope to enter the Atlantic from the Indian Ocean, "the wind is very constant and carries you in 16 or 18 days to the road of the Island" (Tavernier, 1678: 207). The contextual question is why were sailing ships rounding the Cape to enable this 16-daydistant encounter with the island to be made. The brief answer is "trade," for from the $15^{\text {th }}$ Century European maritime nations were exploring the world, seeking to profit from trade, plunder and, in time, colonisation with and of distant lands. One key route was to India and also the Spice Islands (now part of Indonesia). Sailing ships from Europe were at the mercy

\footnotetext{
${ }^{3}$ BL, IOR E/3/87: 202v-203, 9th December 1670.

${ }^{4}$ BL, IOR E/3/87: 175-175v, 9th March 1669.

5 This period was prior to the Act of Union with Scotland in 1707, so references to "England" and "English" rather than "Britain" and "British" are appropriate.
} 


\section{Royle: Island History/St Helena}

of wind systems which saw them pass to the west of St Helena on outward voyages but on the return from the Orient the trade winds, as Tavernier noted, brought the laden ships back close to the island. That St Helena was useful to such returning ships and, thus, was an active participant in global trade can be realised from the comment of a French navigator, Francoise Pyrard who after a voyage in 1611 characterised the island as this "halfway house in the midst of the great ocean" (1890: 300). At the "halfway house" fresh water was available and, thanks to the aforementioned actions of the Portuguese in stocking the island with livestock - principally hogs - as well as planting fruit trees and herbs, some comestibles could be acquired. The Portuguese did not settle St Helena, but tried to keep its existence secret so that its potential for revictualing (resupplying) ships might be reserved for their own vessels. However, following Tavernier's observation, it was inevitable that other trading nations would independently discover the island, leading to the contestation mentioned and the sinking of the Witte Leuw in 1613, a cannon from which is now a central exhibit in St Helena's museum.

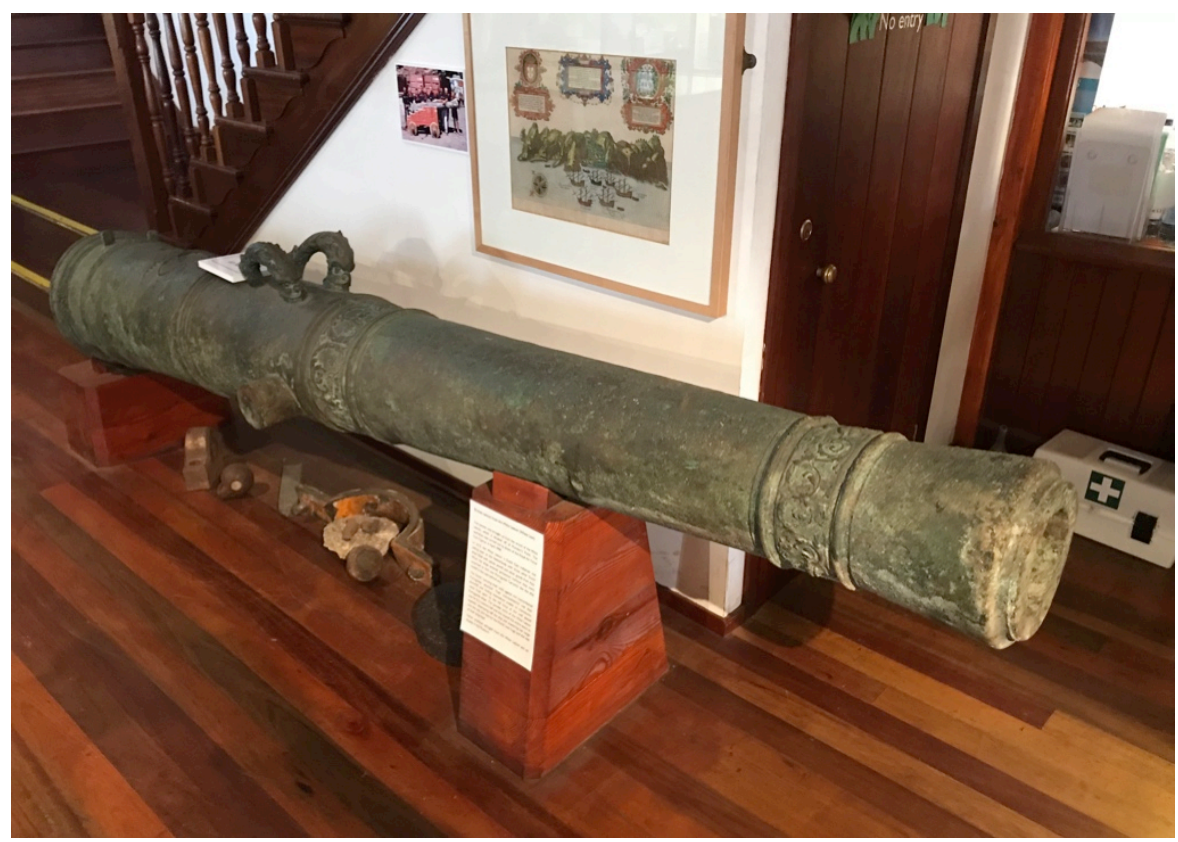

Figure 3 - Cannon from the Witte Leuw. (Photo: Stephen Royle, 2018.)

The English, whose ships had first visited the island in the 1590 o before the establishment of the EIC itself in 16oo, would have been aware of the advantage of sole possession of St Helena. This included not just revictualing but also utilising the island's sheltered "road" or anchorage off the northwest coast as a rendezvous point. EIC ships were first ordered to gather together there from 1649 (Sainsbury, 1912: 318), before these armed merchantmen made their way up through the dangerous waters of Europe in convoy for mutual protection against rival powers. In 1656 the Lord Protector, Oliver Cromwell, was asked to send frigates to St Helena to provide extra security (ibid: 119). There had been a call for the EIC to take possession of St Helena in 1644, but the company did not act until 1659. The action then was again tied in to wider global issues. It was mentioned that the expedition that took St Helena was not assembled originally for that purpose; rather it was to have gone to Run in the Banda 


\section{Royle: Island History/St Helena}

Islands. These islands were the sole sources of nutmeg and mace until the nutmeg tree was transplanted elsewhere in the mid-19th Century. Exploitation and control of the spice trade saw rivalry between the Portuguese, Spanish and later the Dutch, French and British. Vicissitudes in Anglo-Dutch rivalry in the Banda Islands, Europe and elsewhere in the 17th Century explain why Captain Dutton was sent to St Helena not Run in 1659 but then ordered to leave St Helena for Run in 166o. The company did not abandon St Helena when sending Dutton on to his original objective. It was decided to keep possession and, to protect the island against seizure by European rivals, it was fortified and garrisoned. There was a need to maximise St Helena's utility by increasing the supply of food it could offer company ships. Thus, a civilian agricultural population - "planters," assisted by slaves - was introduced to produce the food necessary for the ships and the island's resident administrative and military staff.

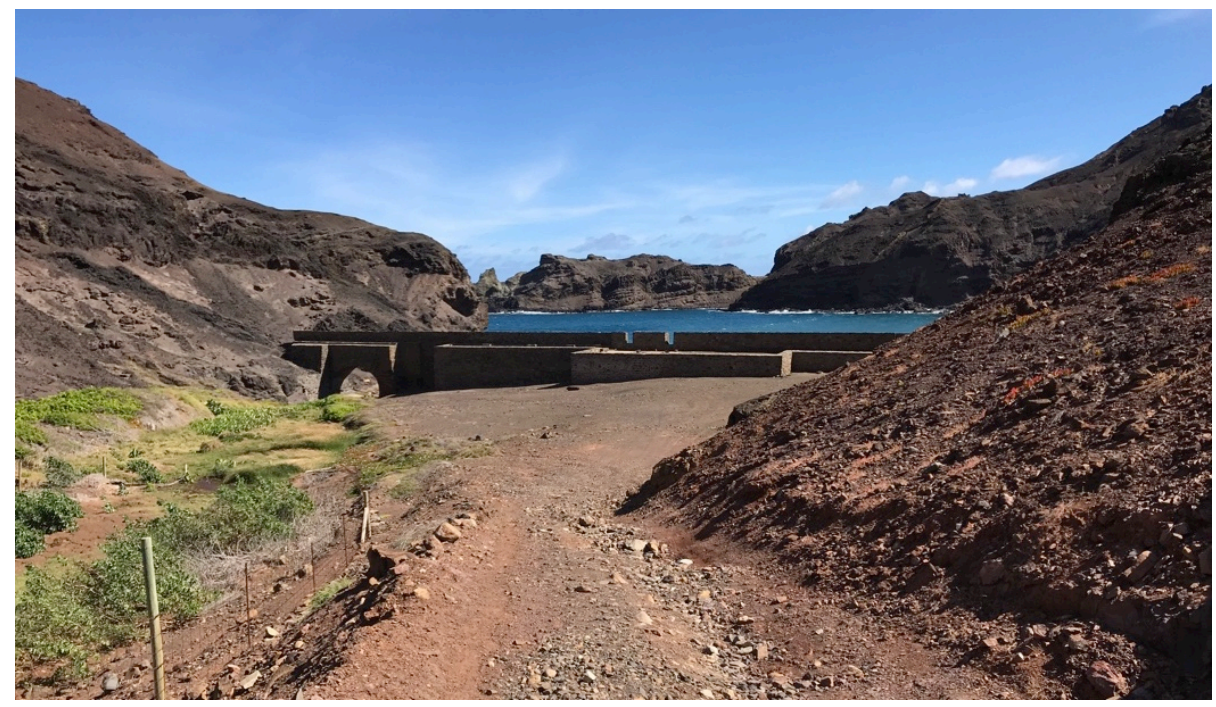

Figure 4 - East India Company fortifications at Sandy Bay. (Photo: Stephen Royle, 2018.)

It was mentioned that the citizens of this new world of St Helena were instructed to "live together in love and amity", just one of many indications of the idealism that underpinned the island's early planning. This utopianism can also be fitted into a wider context. The 17th Century was a challenging period in Europe. Within England there was regicide and the Civil War of 1642-1651 as well as disruption caused by the bubonic plague, culminating in the Great Plague of London in 1665-1666. Writers and thinkers sought different ways of organising affairs, of rearranging society to provide better and, perhaps, more equably, for citizens. That was certainly the aim of the Levellers, a political movement which pressed for equal natural rights during the Civil War (Foxley, 2003). Further, philosophical tomes such as Thomas Hobbe's Leviathan (1651) and Margaret Cavendish's Blazing World (1666) were no doubt discussed amongst the higher echelons of society, including, one assumes, the directors of the EIC. These men had the unusual chance of actually setting up a utopian society on their far-flung island and in a mannered way tried to do just that, indeed with the stated aim of establishing a "levelling constitution". ${ }^{.}$

\footnotetext{
${ }^{6}$ BL, IOR E/3/90: 272v-274v, 6th May 1685.
} 


\section{Royle: Island History/St Helena}

However, the noble aims of the directors hit against the realities, the generalities, of small island life, one of which is the difficulty of defending such a place against a determined invader. Defensive difficulties are compounded in the case of a putative defender aiding the attackers and if there is reluctance amongst defenders to fight, perhaps die, for their cause. Both circumstances pertained to St Helena in 1673. Once the Dutch had established a foothold on the island in a valley that was not fortified - aided by one William Cox, a resident - the garrison, unwilling to die for the EIC, took ship and fled. The company later admitted that Cox had aided the invasion and that resistance was hindered by "ye intemperancy of the inhabitants many of them being found drunk upon the guards". ${ }^{7}$

Just as the EIC could not hold St Helena against invasion, nor could the VOC. A few months after Dutch capture, a fleet led by the Royal Navy frigate, Assistance, in the region to guard EIC ships, learnt of the situation and, "we having noo other business too doo", retook St Helena (Mackenzie, 1994). It was decided to land 350 men from two ships on the undefended north coast, and, with a slave called Black Oliver, who had worked on St Helena, as their guide (for which he was granted his freedom), they were to make their way overland to attack the fort from the rear. Meanwhile, Assistance and three other ships fired broadsides at the defended north-western coast. ${ }^{8}$ The Dutch realised their position was hopeless, "came off with a flagg of truce and surrendered their Isle upon condition that they might not be stripped of their cloaths". ${ }^{9}$ Having taken the island, the English navy reinforced its position with sufficient vessels to see off VOC ships, which arrived subsequently. The EIC had to ask the King for their island back (Sainsbury, 1932: 270). Charles II assented and St Helena was repopulated, but the company had to make provision "for securing the island from again falling into the hands of the enemy" (Sainsbury, 1932: 271).

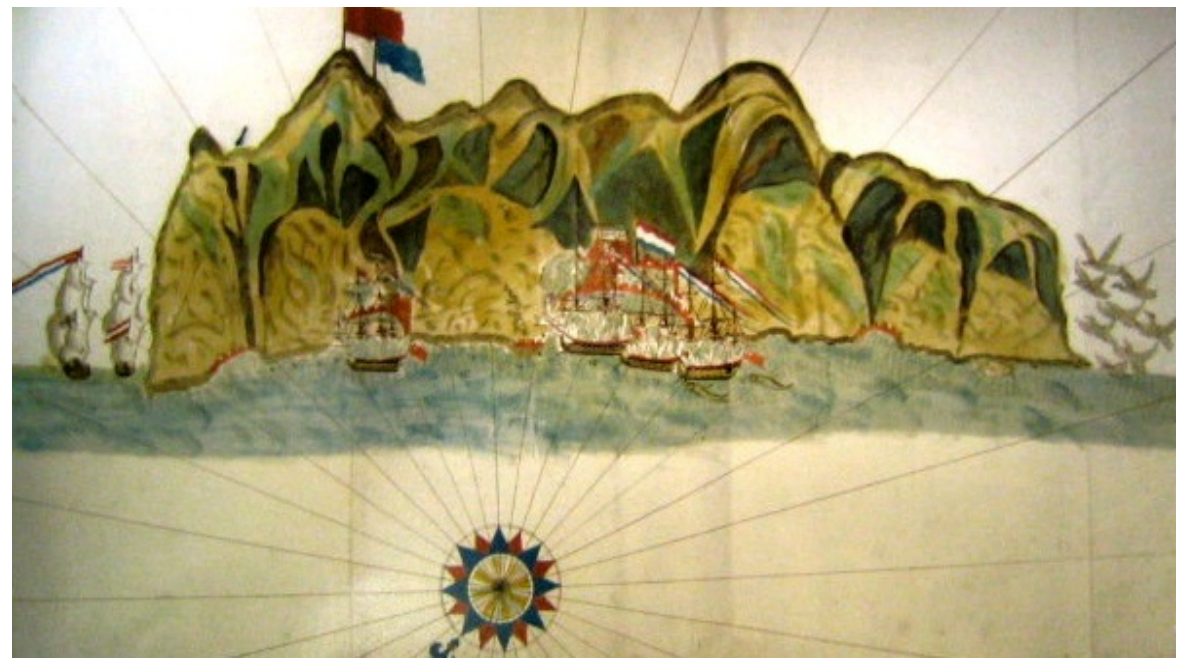

Figure 5 - The 1673 recapture of St Helena. (Pepys Library, Magdalene College, Cambridge)

\footnotetext{
${ }^{7}$ BL, IOR E/3/89: 30v-31, 8th November 1678 .

${ }^{8}$ Pepys Library, Magdalene College Cambridge, PL 2543.

${ }^{9}$ Log of HMS Assistance, Earl of Dartmouth Papers, National Maritime Museum DAR/8.
} 


\section{Royle: Island History/St Helena}

This humiliation altered the company's attitude towards its people on St Helena, resulting from which its society changed from being a "commonwealth of market gardeners" to "a plantation economy in which the erstwhile smallholders became feudal serfs" (Keay, 1993: 179). A quotidian fractiousness developed amongst the EIC servants themselves, between the civilians and the company, and between the whites and their black slaves. The EIC viewed St Helena as a small part of a larger whole; by contrast, to its planters, St Helena was all-important as the place where their life was being spent and from which they wished to extract as comfortable a standard of living as possible. Disputes arose about taxes, also illicit trade between the planters and non-EIC "interloper" ships.

After a situation in 1681 when 50-6o inhabitants had gathered on open land without leave of the Governor, which was seen as fomenting unrest, ${ }^{10}$ council meetings were no longer held in public but behind locked gates at the fort." A warning was issued in 1684 to ships' captains that "some of our planters are mutinously inclined"; ${ }^{12}$ for sedition had occurred that year, stimulated by a dispute between the deputy governor and a soldier, after which the soldier was imprisoned. ${ }^{13}$ This inflamed already poor relations and another soldier, Private William Bowyer, led a rebellion. Bowyer was incensed because he had been imprisoned for illicit trading and reduced to the ranks from being a corporal. Bowyer led about 20 armed soldiers and 30 freemen towards Fort James where they were confronted from within by Governor Blackmore who instructed the guard to open fire with both great and small shot and three civilians were killed, one of whom was Black Oliver. ${ }^{14}$ Subsequently, several soldiers were banished and Bowyer was hanged. The company then pressed the King, James II, to issue a Royal Command for St Helena to be "reduced into a state of obedience", significantly under martial law under which civilians could be court-martialled. Some civilians involved in the sedition were court martialled, their punishments being exile or whipping, but three civilian ringleaders were hanged. ${ }^{15}$ Three women widowed during the sedition then petitioned the House of Commons in London. One was the widow of Private Bowyer; another, Martha Bolton, sought "condign" (appropriate or fitting) punishment for those responsible for her husband's execution under martial law with redress for herself and her children. The third, Grace Colson, declared her civilian husband's execution to have been murder. ${ }^{16}$ The EIC was ordered to appear before the House in May 1689 when an enquiry was held. This focused on the 1685 command of the King to apply martial law to St Helena. A factor was that King James II - by then deposed - was an investor in the EIC, with the implication that he might have been amenable to carry out the company's bidding. The House of Commons ruled that the establishment of martial law had not been lawful, so those executed under it were unlawfully killed. ${ }^{17}$ This was a tremendous blow to the globally significant EIC, whose reputation and activities were thus harmed by events on tiny St Helena.

Civilians on St Helena were thereafter treated with almost as much suspicion as slaves; indeed, the garrison was to lodge within the fort to prevent soldiers "being corrupted by any

${ }^{10}$ BL, IOR E/3/90: 272v-274v, 6th May 1685.

${ }^{11}$ St Helena Archives (SHA), EIC 1/1: 59-63, 12th February 1681.

${ }^{12}$ BL, IOR E/3/90: 252, 26th November 1684 .

${ }^{13}$ BL, IOR G/32/2, St Helena Consultation, 13th October 1684.

${ }^{14}$ BL, Orme Manuscripts, MSS EUR/ORME OV.4: 111-114.

${ }^{15} \mathrm{BL}$, Orme Manuscripts, IOR OV4: 111-14.

${ }^{16}$ Journal of the House of Commons 10 (1688-1693): 135, 139, 151-152, 155-156, $215-216$ and 341.

${ }^{17}$ Journal of the House of Commons 10 (1688-1693): 341. 


\section{Royle: Island History/St Helena}

vicious or rebellious inhabitants". ${ }^{18}$ However, soldiers could be corrupt without civilian instruction. In 1693 Sergeant Henry Jackson led a band of mutineers who shot and killed the Governor, seized the company treasure chest and, having captured a ship's captain, used him and other hostages to commandeer his ship and sail away, never to be heard of again. ${ }^{19}$ Two years later, there came a slave rebellion. Slaves were treated harshly on St Helena, if seldom executed since they were valuable commodities. For example, one slave, Sattoe, was convicted in 1679 for attempting to murder his owner. ${ }^{20}$ Sattoe admitted he had stabbed the man when threatened with yet another beating. He was sentenced to be hanged, but was reprieved after his master - his victim - argued that execution would deprive him of his slave's labour. Sattoe escaped the rope, but not the saw, his right arm being amputated in front of all other slaves as punishment for striking a white person. ${ }^{21}$ The master then applied for compensation on the grounds that his one-armed slave could do less work than before. He was not successful. Such harsh treatment led to resistance and there were rumours in 1679 about slaves having "some evil designe in hand", "tending to the destruction of their masters and all the inhabitants". ${ }^{23}$ In 1684 slaves were restrained "from all idle ramblings and wanderings" on Sunday, their day of rest, their owners liable to fines if a slave was caught wandering. ${ }^{24}$ Despite these precautions, a rebellion was planned in December 1695 . To summarise from the court proceedings, slaves planned first to capture the fort in Lemon Valley, killing the two soldiers on duty. They would steal weapons held there, return to their plantations, get their owners to step outside the house where they would be killed, then rush inside to slaughter the family. Slaves would then gather in Jamestown and take the fort by setting fire to an adjoining house and capturing the soldiers when they ran out to deal with the blaze. Upon the arrival of the next ship, slaves pretending to be a guard of honour were to seize the captain when he paid his courtesy visit ashore and using the captain as hostage, commandeer his ship and sail away to freedom just like Sergeant Jackson planned to do in 1693 .

As association was forbidden, the plot had to be arranged by passing messages between slaves, a dangerous procedure which saw the slaves betrayed by one of their number, Annah, who told her mistress. Eleven slaves were convicted, but given the need to keep them alive to work only three ringleaders were executed.$^{25}$ Others were to "receive great punishment, yea even next unto death, for the deterring of others to act in any such wicked design", so all slaves were required to witness the punishments in Fort James. ${ }^{26}$ There is no suggestion that the St Helena slave rebellion was influenced by similar events elsewhere, it would seem that the local slaves were simply responding to a universal desire for freedom, Paradoxically, St Helena was to become an important base in the suppression of the slave trade in the 19th Century (Fox, 2017).

Study of early St Helena shows that its story was part of a wider history. The events themselves were either a response to universal feelings or were bound up in broader political

\footnotetext{
${ }^{18}$ BL, IOR E/3/90: 272v-274v, 6th May 1685.

${ }^{19}$ SHA, EIC 1/4: 1-4 and EIC 1/4: 22-34; SHA, EIC 1/4: 180-194, 7th and 8th January 1695.

${ }^{20}$ SHA, EIC 1/1: 67-70, 3rd November 1679.

${ }^{21}$ SHA, EIC 1/1: 71-72, 6th November 1679.

${ }^{22}$ SHA, EIC 1/1: 76-84, 22nd December 1679.

${ }^{23}$ SHA, EIC 1/1: 71-72, 6nd November 1679.

${ }^{24}$ SHA, EIC 1/2: 264-275, 22nd June 1686.

${ }^{25}$ SHA, EIC 1/4: 237-251, 3rd December 1695.

${ }^{26}$ SHA, EIC 1/4: 253-260, 16th December 1695.
} 


\section{Royle: Island History/St Helena}

and economic matters, the tiny island being a cog in a much larger and more significant machine.

\section{Islands in history}

History is significant on islands; but islands have not always been significant in the academic subject of history for, as a Dutch historian has put it: "[a]s maritime historians focus on the sea and global historians on the land masses of the world, islands are easily left out or marginalised" (Sicking, 2004: 489). Notwithstanding this observation, there is now evidence that islands are becoming more significant within some branches of history, just as they already have been regarded as important to geography, biology, anthropology and other disciplines. One example of this is a major project sponsored by the British research grant awarding body, the Arts and Humanities Research Council, entitled 'An empire of islands: concepts, contexts and collections'. ${ }^{27}$ This project, led by historians John McAleer of the University of Southampton and Douglas Hamilton of Sheffield Hallam University, studies the role played by islands in the development of the British Empire in the Age of Sail. In unpublished material developing the project McAleer wrote of the islands as occupying "interstitial spaces - geographically, historically, and conceptually ... [which] played crucial roles in forging and maintaining" the Empire. Islands were strategic hubs that defended trade routes and provided opportunities for revictualing, ship repair and refreshment. Hitherto, McAleer noted, the Atlantic world had been seen "in terms of North Atlantic trade, transport and communications links, the growth and development of American and Caribbean colonies, and the slave trade that connected Europe, Africa and the Americas" (ibid). However there was a need to recognise the important and influential part played by mid-Atlantic islands as "fulcra around which Britain's global world turned" (ibid). In some cases islands were even more than this, being actually the prizes of empire because of the produce they generated. Mention was made earlier of Run, the source of nutmeg; other treasures would be the various insular sugar colonies in the Caribbean and the Indian and Pacific Oceans. The wider project, still ongoing as this is written, seeks to establish a network of scholars by arranging a series of workshops to stimulate discussion about islands being hubs which facilitated the expansion and maintenance of empires as well as being often sites of imperial contestation. One partner in the project has been the National Maritime Museum at Greenwich outside London, which has within its collections artefacts and documentation pertaining to this islands and empire theme. An online presence has been established (Royal Museums Greenwich, 2018) and a major publication, Islands and Empire, has been commissioned by Oxford University Press as part of their Oxford History of the British Empire Companion Series. The history of the British Empire was not a history of islands - India was the jewel in the crown - but the contribution of islands to that Empire was more important than their physical size would seem to warrant.

\section{Conclusion}

This article has made distinctions between "story" and "study" - between "description" and "analysis" - within both history and island studies, with particular reference to the case of St Helena in the 17th Century. A catalogue of events on the island - the story - was set against a deeper approach, which placed these events into their wider spatial and political contexts - the history. The tiny and remote island was an important cog in a near global imperial machine, given its role in the operation of the EIC. The company impacted the

\footnotetext{
${ }^{27}$ AHRC award: AH/Noo3225/1.
} 


\section{Royle: Island History/St Helena}

island in every way, of course, but, not least in the aftermath of the illegal executions following the 1684 mutiny when the EIC was castigated in the English Parliament, the island also affected the mighty company. The way in which islands are more significant than would seem to be warranted by their size has long been recognised within subjects such as geography, anthropology and biology. There is now evidence to suggest that history, at least imperial history, is beginning to appreciate the significance of islands to its discourses, notwithstanding the observation by Sicking (2014) that islands have been marginalised in historical studies.

\section{BIBLIOGRAPHY}

Ballantyne, R.M (1858) The Coral Island: A Tale of the Pacific Ocean, Edinburgh: T. Nelson and Sons

Boxer, C.R (1930) 'The Third Dutch War in the East (1672-4)', Mariners' Mirror v16:343-386

Cavendish, M, the Duchess of Newcastle (1666) The Description of the New World, Called the Blazing World, London: A. Maxwell

Defoe, D (1719) The Life and Strange Adventures of Robinson Crusoe of York, Mariner, London: W. Taylor

Fox, C (2017) A Bitter Draught: St Helena and the Abolition of Slavery, London: Society of Friends of St Helena

Foxley, R (2013) The Levellers: Radical Political Thought in the English Revolution, Oxford: Oxford University Press

Golding, W (1954) Lord of the Flies, London: Faber and Faber

Hobbes, T (1651) Leviathan or the Matter, Forme and Power of a Common-Wealth Ecclesiasticall and Civil, London: Andrew Crooke

Keay, J (1991) The Honourable Company: A History of the East India Company, London: HarperCollins

Kinane, I (2016) Theorising Literary Islands: The Island Trope in Contemporary Robinsonade Narratives, London: Rowman and Littlefield International

Mackenzie, I (1994) The Retaking of St Helena 1673: 'We Having Noo Other Business too Doo', Conference paper, Vincennes: Service Historique de la Marine, National Maritime Museum, PBP 4877

Maclean, C (2006) Island on the Edge of the World: The Story of St Kilda, Edinburgh: Canongate

Martin, M (1703) A Description of the Western Isles of Scotland, London: Andrew Bell 


\section{Royle: Island History/St Helena}

Monro, D (1805) Description of the Western Isles of Scotland, called Hybrides; by Mr Donald Monro High Dean of the Isles who travelled through most of them in the year 1549, Edinburgh: Archibald Constable

Pyrard, F (1890) The Voyage of François Pyrard of Laval to the East Indies, the Maldives, the Moluccas and Brazil Volume 3, London: Hakluyt Society

Royal Museums Greenwich (2018) An Empire of Islands, rmg.co.uk/empire_islands accessed 27 November 2018

Royle, S.A (2007) The Company's Island: St Helena, Company Colonies and the Colonial Endeavour, London: IB Tauris

Sainsbury, E.B (1912) A Calendar of the Court Minutes etc of the East India Company 16441649, Oxford: Clarendon Press

----- (1916) A Calendar of the Court Minutes etc of the East India Company 1655-1659, Oxford: Clarendon Press

----- (1932) A Calendar of the Court Minutes etc of the East India Company 1671-1673, Oxford: Clarendon Press

Sicking, L (2014) 'Islands and Maritime Connection: Networks and Empires, 1200-1700', International Journal of Maritime History v26 n3: 489-493

Tavernier, J.B (1678) The Six Voyages of John Baptista Tavernier a Nobleman of France Now Living through Turkey into Persia and the East Indies Finished in the Year 1670, London: RL and MP 